\title{
Effects of external financial flows on income inequality in selected Southern African Development Community member states
}

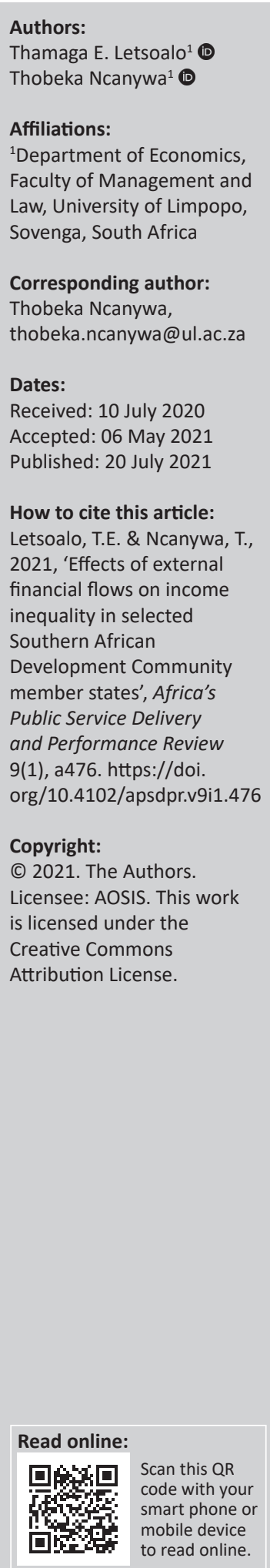

Background: The developmental goals of various emerging markets are quantitative targets set to reduce income inequality, alleviate poverty, reduce unemployment and achieve continuous inclusive economic growth amongst other key economic performance indicators. The interest is mainly on what can be done on economic performance to fight escalating inequality, increase economic growth and maintain low inflation amongst other economic indicators.

Aim: The study investigates the effects of external financial flows on income inequality in the Southern African Development Community (SADC) region.

Setting: The study shows the long-run stable relationship between the set of variables.

Methods: The study have used the panel cointegration, autoregressive distributed lag and causality techniques.

Results: The findings are that in the long run, remittances can strongly reduce income inequality, foreign direct investment (FDI) and cross border bank lending have an increasing effect and foreign aid can weakly reduce inequality. In the short run, FDI and cross border bank lending can strongly explain income inequality, and negative remittances and foreign aid are insignificantly explaining income inequality. Furthermore, the evidence from panel causality confirms the bidirectional causality amongst remittances, cross border bank lending and income inequality, and unidirectional causality in other sets of variables.

Conclusion: It can be concluded that external financial flows can play a vital role to reduce persistent income inequality in the SADC region. It is recommended that the SADC governments need to formulate policies on remittances as they have positive returns on human capital, strengthen foreign aid institutions and create conducive environment to attract FDI.

Keywords: remittances; foreign direct investment; income inequality; autoregressive distributed lag; cross border bank lending; foreign aid.

\section{Introduction}

There is a continuous debate amongst economists and policy-oriented researchers regarding the relative impact of international financial flows on economic performance in both developing and developed countries. The interest is mainly on what can be done on economic performance to fight escalating inequality, increase economic growth and maintain low inflation amongst other economic indicators. It is observed that the Southern African Development Community (SADC) region has high income inequality that has detrimental effects towards governments (Linardi \& Rudra 2016). Income inequality is high in the SADC because of past policy failures of the postcolonial governments despite a rapid increase in economic growth (Ostry, Berg \& Tsangarides 2014). This article aims to find if external financial flows can reduce income inequality. This is pursued in the SADC with some selected countries, namely South Africa, Botswana, Tanzania, Malawi, Mauritius, Zambia, Angola, Mozambique and Madagascar. These countries are selected on the basis of availability of data (World Bank 2020).

This article attempts to solve challenges of the SADC region as the most unequal region as reported in the World Bank (2020). For instance, South Africa, Namibia and Botswana are at the top of the world's most unequal countries, South Africa leading the group with the Gini coefficient of 69.6. Additionally, the level of income inequality in the region is on the perpetual rise. For instance, income distributed of the SADC member states is skewed in that, the income share of the $10 \%$ at the top continuously increase by $15 \%$ at the expense of the states in the bottom 50\% (World Bank 2020; Figure 1). Figure 1 shows that the bottom $50 \%$ of the population has suffered a perpetual decline in income share from 


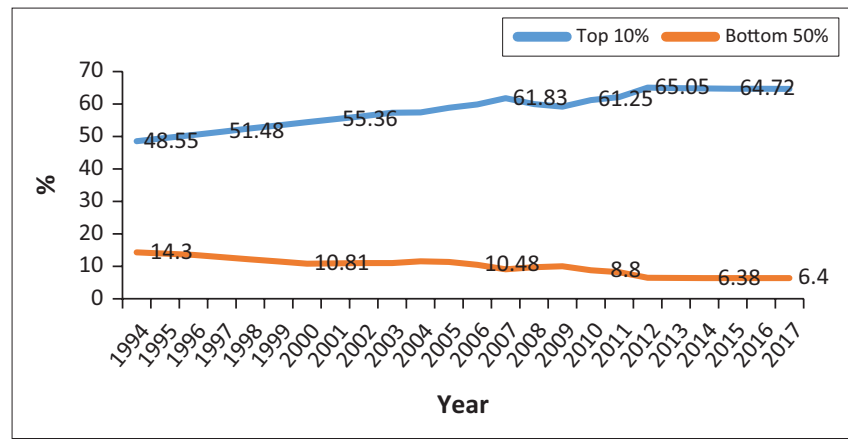

Note: SADC top $10 \%$ and bottom $50 \%$ income share.

FIGURE 1: Southern African Development Community income distributed, 1994-2017.

1994 to 2017. The bottom 50\% of the population has lost approximately $7.9 \%$ of income between 1995 and 2017 in the SADC region, in the progress making it the most unequal region in the world. The higher income inequality in the SADC region reflects negatively in opportunities to produce, which in this case results in lowering economic growth in the region (Claessens \& Perotti 2005).

Financial flows refer to the movement of money for the purpose of investment, trade or business production, including the flow of capital within corporations in the form of investment capital (Adams \& Klobodu 2017).

Several studies documented contradicting views between financial flows and income inequality. For instance, some noted that financial flows could assist in reducing income inequality amongst other economic ills (Anyanwu 2011; Herzer, Hühne \& Nunnenkamp 2014; Koechlin \& Leon 2007; Shafiullah 2011). Other scholars like Adams and Klobodum (2017) found no effects of financial flows on income inequality, and Anyanwu (2011) found a positive relationship in North Africa between the two. These contradicting findings indicate that there is a research gap with respect to this relationship especially in the SADC region. Moreover, the novelty rests on the findings of which financial flow indicator can drastically reduce income inequality, particularly when the robust econometric methodologies are employed in this study.

Financial flows adopted in this study are remittances, foreign direct investment (FDI), foreign aid and cross border bank lending. Remittances are a transfer of money from international migrants to an individual member in their country of origin (Bang, Mitra \& Wunnava 2016). Foreign direct investment is an investment in a business by an investor from another country for which the foreign investor has control over the company purchased (Sylwester 2005). Foreign aid refers to money that one country voluntarily transfers to another, which can take the form of a gift, a grant or a loan (Easterly 2008). Cross border bank lending refers to a measure of foreign bank lending to finance the country's balance sheet account, especially if there was a financial crisis in the foreign exchange reserves (Bremus \& Fratzscher 2015). Many economies around the globe strengthened their financial sectors and embarked on market reforms to attract the inflow of external capital.
The external financial flows are of paramount importance for the developmental purposes of host countries in terms of skill advancement, accelerating cross-border transfer of technology, knowledge and advanced financial markets (Bremus \& Fratzscher 2015). Additionally, it is alluded in Bansal (2004) that financial flow can be a channel to transfer managerial skills, integration into international marketing, production networks, improving the international competitiveness of firms and ultimately the economic performance of host countries. The empirical evidence from studies confirms that financial flows lead to improved domestic investment, and increase aggregate stock and productivity to host countries (Bremus \& Fratzscher 2015; Sylwester 2005). Hence, this article aims to investigate effects of external financial flows such as remittances, FDI, foreign aid and cross border bank lending on income inequality in the SADC region. The article is structured as follows: this section is followed by 'Literature review', then the 'Methodology' section, and thereafter 'Empirical results and discussion' section follows, and finally is the 'Conclusion and recommendations' section.

\section{Literature review}

This section discusses both the theoretical and empirical literature on the role which external financial flows can play on income inequality.

\section{Theoretical literature}

The standard neoclassical view on capital flows and the integral part played by markets on the development of countries is crucial to macroeconomics. The view maintains that external financial flows are important financial resources which function as equalising forces and bring fast access of capital to household and countries (Choi 2006). It is ideal that external financial flows can influence income distributed in a neoclassical paradigm (Adams \& Klobodum 2017). This can be done through liberalisation of financial flows and integration of the world economy, as this has proved to deteriorate income inequality of nations. Deardorff and Stern (eds. 1994) argued that the benefits of capital, foreign or domestic flows spread throughout the whole economy. Financial flows deteriorate income inequality because of raised wages in all sectors as opposed to traditional sectors. The flow of capital will see out the highest rates of return in host countries.

The famous Stolper-Sammuelson theorem indicates a link between free flow of capital and income inequality (Stolper \& Samuelson 1941). The theorem indicates that if trade liberalisation is increased in developing countries, import taxes are reduced and capital inflows are encouraged; the labour force, which is mostly unskilled labour in developing countries, benefits whilst the high-skilled labour earnings decrease, thereby reducing income inequality. The deteriorating income inequality in emerging economies as a result of capital inflow has been covered by many studies (Marjit, Beladi \& Chakrabarti 2004). The studies revealed that 
the influx of foreign capital might produce harmful results on wage inequalities given the structural setup of less developed countries. The empirical studies conducted in several countries confirm a positive relationship between the high-skilled labour and inflow of capital in developing countries (Marjit et al. 2004). The inflow of external capital increases the labour earning of low-income household and improves distributed of income in host countries. The article empirically examined the effects of external financial flow variables on income inequality in selected SADC member states. Specifically, external financial flows measured by remittances, FDI, foreign aid and cross border bank lending are regressed on income inequality.

\section{Empirical literature}

The inflow of finance could lessen the cost of capital and consequently raise investment thereby curbing unemployment in the host country. Moreover, the income earned by labour is the primary source of income particularly to the poor in the low-income households (Beer 2015; Lin, Kim \& Wu 2013). The perpetual inflow of external finance into economies with limited resources could enlarge the middle class, increase employment and increase the savings rate within the needy people, resulting in reduced income inequality (Beer 2015). External financial flows can help to reduce income inequality when they are channelled to the lower income and unskilled labour (Choi 2006). Adams and Klobodu (2017) argue that inflow of capital could aid in reducing the cost of capital and as a result increase investment and reduce dire unemployment rate in developing countries. Furthermore, labour and households are regarded as the first beneficiaries of the external capital inflows, and this improves the income distributed on abundant low-skilled labour in the recipient countries. However, the literature available on the effects of external financial flows on income inequality remains largely inconclusive across diverse empirical studies.

Some studies scrutinised effects of FDI on income inequalities in both developing and developed countries covering a wide range of empirical evidence (Herzer et al. 2014; Jensen \& Rosas 2007; Te Velde 2003). For example, Herzer et al. (2014) used panel cointegration to show that FDI can reduce income inequality. Most researchers found that the more countries attract FDI, the more they reduce income inequality, meaning there is a negative relationship between the two (Jensen \& Rosas 2007; Te Velde 2003). The absorption capacity, education and economic development influence the positive relationship between income inequality and FDI (Choi 2006; Wu \& Hsu 2012). It has also been documented in Bhandari (2007) and Sylwester (2005) that in some countries FDI had no effect on income inequality.

Empirical association of remittances with income inequality has been well-documented in developed and less-developed countries with contradicting views. For instance, some researchers found that remittances reduce income inequality
(Adams et al. 2008; Bang et al. 2016; Jones 1998; Koechlin \& Leon 2007; Milanovic 1987). Other studies distinguished that the indirect remittance-inequality nexus affects rural communities more (Jones 1998; Taylor 1992). In Anyanwu (2011), it was declared that remittances reduced income inequality in Northern Africa but had opposite effects in the sub-Saharan African countries. Contrary to this are studies that found remittances having a positive relationship with income inequality. For example, Barham and Boucher (1998) and Adger (1999) concluded that remittances increased income inequality. If the remittances can reduce income inequality, this can be beneficial for economic development of countries, especially to the agricultural economy, uplift welfare of citizens, reduce poverty and bring political stability.

There is generally a weak link between foreign aid and income inequality, and even when it is significant, it does not convincingly reduce income inequality (Saidon et al. 2013; Shafiullah 2011). It has been found in Shafiullah (2011) that as much as there is a negative relationship between the two, some results were insignificant. Chong, Gradstein and Calderon (2009) mentioned that this weak link is attributed to the quality of institutions, which lead to inefficient associations. Bjørnskov (2010) established that income inequality can be reduced by foreign aid in democratic countries. However, some studies found a positive relationship between the inflow of foreign aid and income inequality (Ali \& Ahmed 2013; Herzer \& Nunnenkamp 2012). Chong et al. (2009) did not realise any role that foreign aid could play on income inequality.

Cross border bank lending affects the balance sheet account more and can be used to balance supply and demand of foreign assets. It has been shown in Jaumotte, Lall and Papageorgiou (2013) that capital moving across borders can weaken the Stolper-Samuelson theorem, as there is increase in inequality. Lending abroad without addressing income inequality has been found to result in more indebtedness of the poor households by Ranciere et al. (2012). Some studies discovered that cross border bank lending did not reduce income inequality (Jaumotte et al. 2013; Ranciere et al. 2012). However, other studies found cross border bank lending had a decreasing effect on income inequality, particularly in countries that have developed banking systems (Focarelli \& Pozzolo 2001).

\section{Methodology}

This section addresses issues of data, the estimated model and the estimation techniques using econometric methods in some selected SADC member states. The quantitative econometric analysis adopted a panel autoregressive distributed lag (ARDL) of the SADC region.

\section{Data}

An annual panel dataset, which includes nine SADC member states (South Africa, Botswana, Tanzania, Malawi, Mauritius, 
Zambia, Angola, Mozambique and Madagascar), is utilised to attain the aim of the study, where these countries are selected on the basis of availability of data. Data on all variables except for the Gini index were sourced from the World Bank for the period 1995-2018. The Gini coefficients were obtained from the Standardised World Income Inequality Database (SWIID) which offers wide-ranging dataset as compared to other alternative data providers. Adams and Klobodu (2017) maintained that these dataset afford researchers and analysts to compare Gini estimates and cover a large sample size which makes it suitable for cross-country studies. It has been pinpointed that SWIID offers more than 670 observations, whilst other database institutions such as World Income Inequality Database and World Bank generate around 150 and 190 observations, respectively (Adams \& Klobodu 2017).

\section{Model specification}

To realise the set aim of the study, the study adopted the external financial flow variables that could affect income inequality from work discussed in the literature review section and a linear model was developed as follows:

$$
L I N Q_{i t}=\alpha_{i t}+\beta_{1} L_{R E M_{i t}}+\beta_{2} L F D I_{i t}+\beta_{3} L F A I_{i t}+\beta_{4} L C B F_{i t}+\varepsilon_{i t}
$$

[Eqn 1]

where, $\mathrm{L}$ denotes that all variables were transformed into natural logarithms, $\propto$ represents a constant parameter, $\beta_{1}$ to $\beta_{4}$ represent the coefficients of the independent variables, $\varepsilon_{i t}$ represents the error term, $L R E M$ denotes remittances sourced in percentages of GDP, $L F D I$ denotes the FDI as it was extracted as the net-inflows of FDI as a percentage of GDP, LFAI denotes foreign aid proxy by the oversee development assistance obtained as percentages of the GDP, $L C D F$ denotes cross border bank lending proxy by net commercial bank lending and other private credits, and $L I N Q$ denotes the income inequality proxy by the Gini index.

\section{Estimation techniques}

This study used a panel ARDL and Granger causality techniques to model the effects of external financial flows on income inequality in selected SADC member states. To choose the best methodology, a panel data unit root test is a necessary pre-test for the analysis.

\section{The panel data unit root tests}

To obtain robust and reliable results, the study conducted several panel unit root tests to understand the properties of the panel data employed. Understanding the nature of the data utilised helps in choosing a suitable technique for panel regression. The vast majority of literature suggests that individual unit root tests lack power in contrast to panel unit root tests (Ncanywa \& Mabusela 2019). The panel unit root technique is advantageous as it considers both the time-series dimension and the cross-sectional dimension behaviour of variables. There is an autoregressive process on cross-sections or on the series. Therefore, panel regressions follow an autoregressive process:

$Y_{i t}=p_{i} Y_{i t-1}+X_{i t} \delta_{i}+\varepsilon_{i t}$

where $i=1,2, \ldots, N$ denotes cross-section units in Equation 2, and $t=1,2, \ldots, T_{t}$ denotes time series. $X_{i t}$ denotes the external variables and the process includes any single trends and fixed effects. The autoregressive estimates are represented by $p_{i t}$ and the error term $\varepsilon_{i t}$ which are equally independent. The following panel unit roots are used: Levin, Lin and Chu; Breitung and Hadri; Im, Pesaran and Shin; Fisher-ADF and Fisher-PP (Breitung \& Pesaran 2008).

\section{Panel cointegration test}

This study determined the long-run cointegration linkage between external financial flow and income inequality. This is necessary and paramount after determination of order of integration from the panel unit root tests. For the purpose of the study, the Kao, Pedroni and Fisher (combined Johansen) tests are employed to check the existence of the long-run cointegration relationship between the external financial flow variables and income inequality. There is cointegration if the tests yield probabilities that are significant at $1 \%, 5 \%$ or $10 \%$.

\section{Panel autoregressive distributed lag}

The study modelled the effects of several external financial flow variables on income inequality through the panel ARDL method endorsed by Pesaran, Shin and Smith (1999). The panel technique, also termed the pooled mean group (PGM) ARDL estimator, adopts the cointegration from the ordinary ARDL and amends it to suit the panel data by allowing the constant, short-run and long-run coefficients to fluctuate across cross-sections (Pesaran et al. 1999).

PGM ARDL model is formulated as follows:

$\Delta Y_{i, t}=\phi_{i} E C_{i, t}+\Sigma_{j=0}^{q-1} \Delta X_{1, t-j^{\prime}} \beta_{i, j}+\Sigma_{j-1}^{p-1} \lambda_{i, j} * \Delta Y_{i, t-j}+\varepsilon_{i, t} \quad$ [Eqn 3]

Where:

$E C_{i, t}=Y_{i, t-1}-X_{i, t}^{\prime} \theta$

The technique assumes that the independent variables and dependent variables have same number of lags in each side; however, it is not a requirement for estimation (Breitung \& Pesaran 2008). The study thus developed a PGM ARDL panel regression model to obtain the long-run and short-run coefficients of the external financial flows on income inequality:

$$
\begin{aligned}
\Delta \operatorname{LINQ}_{i t}= & \alpha_{i t} E C_{i t}+\sum_{j=0}^{q-1} \beta_{1} L_{R E M_{i t}}+\sum_{j=0}^{q-1} \beta_{2} L F D I_{i t} \\
& +\sum_{j=0}^{q-1} \beta_{3} L F A I_{i t}+\sum_{j=0}^{q-1} \beta_{4} L C B F_{i t}+\delta_{1} L R E M_{i t} \quad \text { [Eqn 5] } \\
& +\delta_{2} L F D I_{i t}+\delta_{3} L F A I_{i t}+\delta_{4} L C B F_{i t}+\delta_{i t} E C M_{i t} \varepsilon_{i t}
\end{aligned}
$$

where abbreviated variables are as explained in Equation 1. The error correction model is integrated into the short-run coefficients of the external financial flow variables to capture the speed of adjustment towards the equilibrium state. The 
speed of adjustment reveals the speed with which variables in the model converge towards the equilibrium state.

\section{Stability test}

The stability of the estimated income inequality model is determined to ensure that the developed and adopted model is stable. The test is a diagnostic test used to determine if the model is reliable or meets the properties of a good model. The graphical illustration of the inverse root of autoregressive characteristic polynomial is relied on by the study in question for stability testing. The rule of thumb is that if all roots are inside the unit circle, the estimated model will be regarded as stable and it should be considered adequate in a statistical sense.

\section{Panel Granger causality tests}

The panel Granger causality test is utilised to check the causal relationship between the external financial flow variables and income inequality in selected SADC member states. Panel Granger causality tests take several forms; however, they rely predominantly on the assumptions of the structure of data employed. The analysis estimated the panel causality relationship by estimating the bivariate regressions. In essence, the panel Granger causality test is similar to that of a single series, but the panel method employed by the study in question considers both the cross-sectional dependency and heterogeneity to accommodate the structure of panel data (Pesaran et al. 1999). The decision that there is causality is indicated by significant probabilities of the results.

\section{Empirical results and discussions}

The initial step towards realising the principal aim of the empirical analysis is to establish the unit root properties of the panel series employed. Therefore, the analysis utilised several panel stationarity techniques to test for panel stationarity on all variables employed in the study. Table 1 presents the panel unit root results for all variables employed using three various panel techniques.

In Table 1, the LLC, IPS and Fisher-ADF test results confirmed that income inequality is integrated at order 1.

This means that income inequality becomes stationary after the first difference. All other variables are confirmed to be integrated at order I (0). The IPS confirms that remittances have some cross sections without unit root whilst other depicts unit root. The study recognised that variables employed are integrated at both I (0) and I (1). After realisation that there are different orders of integration in the variables under study, the test of cointegration was undertaken. The cointegration tests are useful to determine if there are long-run effects in the chosen series (Breitung \& Pesaran 2008). Tables 2-4 report cointegration test results of Kao, Pedroni and Fisher.

In Table 2, the Kao cointegration test indicates that there is cointegration. In Table 3, out of the seven Pedroni statistics,
TABLE 1: Panel unit roots test results.

\begin{tabular}{|c|c|c|c|c|}
\hline $\begin{array}{l}\text { Variables } \\
\text { employed in } \\
\text { the analysis }\end{array}$ & Tests & Test models & I (0) [level] & $\begin{array}{l}\text { I (1) [first } \\
\text { difference] }\end{array}$ \\
\hline \multirow[t]{8}{*}{ LINQ } & LLC & Individual and constant & 0.5299 & 0.0004 \\
\hline & & $\begin{array}{l}\text { Individual, constant and } \\
\text { linear trend }\end{array}$ & 0.9390 & 0.0586 \\
\hline & & None & 0.7088 & 0.0000 \\
\hline & IPS & Individual and constant & 0.0944 & 0.0000 \\
\hline & & $\begin{array}{l}\text { Individual, constant and } \\
\text { linear trend }\end{array}$ & 0.7238 & 0.0000 \\
\hline & Fisher-ADF & Individual and constant & 0.2012 & 0.0000 \\
\hline & & $\begin{array}{l}\text { Individual, constant and } \\
\text { linear trend }\end{array}$ & 0.7684 & 0.0000 \\
\hline & & None & 0.9788 & 0.0000 \\
\hline \multirow[t]{8}{*}{ REM } & LLC & Individual and constant & 0.0008 & - \\
\hline & & $\begin{array}{l}\text { Individual, constant and } \\
\text { linear trend }\end{array}$ & 0.1956 & 0.0011 \\
\hline & & None & 0.0052 & - \\
\hline & IPS & Individual and constant & 0.1507 & 0.0000 \\
\hline & & $\begin{array}{l}\text { Individual, constant and } \\
\text { linear trend }\end{array}$ & 0.4243 & 0.0002 \\
\hline & Fisher-ADF & Individual and constant & 0.0012 & - \\
\hline & & $\begin{array}{l}\text { Individual, constant and } \\
\text { linear trend }\end{array}$ & 0.0082 & - \\
\hline & & None & 0.0355 & \\
\hline \multirow[t]{8}{*}{ LFDI } & LLC & Individual and constant & 0.0086 & - \\
\hline & & $\begin{array}{l}\text { Individual, constant and } \\
\text { linear trend }\end{array}$ & 0.2492 & 0.0000 \\
\hline & & None & 0.0001 & - \\
\hline & IPS & Individual and constant & 0.0015 & - \\
\hline & & $\begin{array}{l}\text { Individual, constant and } \\
\text { linear trend }\end{array}$ & 0.1147 & 0.0000 \\
\hline & Fisher-ADF & Individual and constant & 0.0047 & - \\
\hline & & $\begin{array}{l}\text { Individual, constant and } \\
\text { linear trend }\end{array}$ & 0.1860 & 0.0000 \\
\hline & & None & 0.0149 & - \\
\hline \multirow[t]{8}{*}{ LFAI } & LLC & Individual and constant & 0.0153 & - \\
\hline & & $\begin{array}{l}\text { Individual, constant and } \\
\text { linear trend }\end{array}$ & 0.0667 & - \\
\hline & & None & 0.0004 & - \\
\hline & IPS & Individual and constant & 0.0337 & - \\
\hline & & $\begin{array}{l}\text { Individual, constant and } \\
\text { linear trend }\end{array}$ & 0.0266 & - \\
\hline & Fisher-ADF & Individual and constant & 0.0835 & - \\
\hline & & $\begin{array}{l}\text { Individual, constant and } \\
\text { linear trend }\end{array}$ & 0.0607 & - \\
\hline & & None & 0.0067 & - \\
\hline \multirow[t]{8}{*}{ LCLB } & LLC & Individual and constant & 0.3362 & - \\
\hline & & $\begin{array}{l}\text { Individual, constant and } \\
\text { linear trend }\end{array}$ & 0.0057 & - \\
\hline & & None & 0.0000 & - \\
\hline & IPS & Individual and constant & 0.0020 & - \\
\hline & & $\begin{array}{l}\text { Individual, constant and } \\
\text { linear trend }\end{array}$ & 0.0034 & - \\
\hline & Fisher-ADF & Individual and constant & 0.0042 & - \\
\hline & & $\begin{array}{l}\text { Individual, constant and } \\
\text { linear trend }\end{array}$ & 0.0057 & - \\
\hline & & None & 0.0000 & 0.0000 \\
\hline
\end{tabular}

LINQ, logged income inequality; REM, remittances; LFDI, logged foreign direct investment; LFAI, logged foreign aid; LCLB, cross border bank lending; LLC, Levin-Lin-Chu; IPS, Im-PesaranShin (IPS); ADF, Augmented Dickey-Fuller.

four indicate presence of cointegration. Table 4 indicates two co-integrating vectors both at trace and at maximumEigen tests. These cointegration results imply that there is a long-run relationship between the chosen external financial flows and income inequality. This is supported in literature by Jalil and Feridun (2011), Heshmati (2003), Koechlin and Leon (2007), and Ang (2010), who discovered that finance indicators can influence income inequality in the long term. 
TABLE 2: Kao panel cointegration test results.

\begin{tabular}{lcc}
\hline Variable & $\boldsymbol{t}$-statistics & $\boldsymbol{p}$ \\
\hline Augmented Dicky-Fuller & -2.646520 & 0.0041 \\
Residual variance & 0.000795 & - \\
HAC variance & 0.000525 & - \\
\hline
\end{tabular}

$\mathrm{HAC}$, Heteroscedasticity and autocorrelation consistent.

TABLE 3: Pedroni cointegration test results.

\begin{tabular}{lcccc}
\hline Variable & Statistics & Probability & $\begin{array}{c}\text { Weighted } \\
\text { statistics }\end{array}$ & Probability \\
\hline Common AR estimates & & & & \\
Panel V-statistic & 0.430275 & 0.3335 & -1.708558 & 0.9562 \\
Panel rho-statistic & -0.989943 & 0.1611 & 0.134729 & 0.5536 \\
Panel PP-statistic & -5.152608 & 0.0000 & -2.603008 & 0.0046 \\
Panel ADF-statistic & -4.078908 & 0.0000 & -2.392680 & 0.0084 \\
Individual AR estimates & & & & \\
Group rho-statistic & 0.736922 & 0.7694 & - & - \\
Group PP-statistic & -3.998717 & 0.0000 & - & - \\
Group ADF-statistic & -3.324153 & 0.0004 & - & - \\
\hline
\end{tabular}

AR, autoregressive; PP, Phillips-Perron; ADF, Augmented Dickey-Fuller.

TABLE 4: Fisher cointegration test results.

\begin{tabular}{lcccc}
\hline $\begin{array}{l}\text { Hypothesised } \\
\text { number of } \\
\text { cointegrating } \\
\text { equation(s) }\end{array}$ & $\begin{array}{c}\text { Fisher statistics } \\
\text { (trace test) }\end{array}$ & Probability & $\begin{array}{c}\text { Fisher statistics } \\
\text { (max-Eigen test) }\end{array}$ & Probability \\
\hline None & 142.6 & 0.0000 & 105.9 & 0.0000 \\
At most 1 & 58.07 & 0.0000 & 38.67 & 0.0032 \\
At most 2 & 31.53 & 0.0250 & 22.65 & 0.2042 \\
At most 3 & 21.01 & 0.2787 & 13.29 & 0.7740 \\
At most 4 & 35.72 & 0.0077 & 35.72 & 0.0077 \\
\hline
\end{tabular}

The existence of long-run effects in the external financial flow-inequality nexus allows for determination of both short- and long-run estimates. On that regard and based on the results of the unit roots, the panel ARDL estimator is used to find the estimates. Table 5 reports short-run, long-run and error correction term results.

Table 5 shows that remittances can strongly reduce income inequality in the long run, but are insignificant in the short run. These results are in line with the findings of Bang et al. (2016) and Koechlin and Leon (2007) amongst others that remittances play an important role in reducing income inequality. This is more beneficial to the SADC region which comprises of countries with many rural villages as alluded in Jones (1998). Additionally, Table 6 strengthens this relationship in that there is a bidirectional causality between remittances and income inequality. This implies that remittances can reduce income inequality as much as a less unequal state can increase remittances. This is more valuable to the SADC region as there is mobility across states and can eradicate the issues of xenophobia and allow foreigners to live in peace in the region.

Foreign direct investment can strongly influence income inequality both in the short and long run (Table 5). In the short run, FDI can reduce income inequality whereas in the long run, it has an increasing effect. It was mentioned in literature that the behaviour of the FDI effects depend on issues such as the development state of a country, level of education of citizens and the country's absorption capacity (Choi 2006; Wu
TABLE 5: The panel autoregressive distributed lag estimation results.

\begin{tabular}{lcccc}
\hline Variable & Coefficient & Standard error & $t$-statistics & Probability \\
\hline Long-run estimates & & & & \\
Remittances & -0.102127 & 0.034152 & -2.990356 & 0.0032 \\
FDI & 0.208882 & 0.047277 & 4.418290 & 0.0000 \\
Foreign aid & -0.000267 & 0.010324 & -0.025842 & 0.9794 \\
CBBL & 0.073188 & 0.018917 & 3.868882 & 0.0002 \\
Short-run estimates & & & & \\
COINTEQ01 & -0.467573 & 0.091017 & -5.137211 & 0.0000 \\
D(Remittance) & -2.570002 & 6.129070 & -0.419314 & 0.6755 \\
D(FDI) & -0.149876 & 0.061116 & -2.452341 & 0.0152 \\
D(Foreign aid) & -0.379931 & 0.264639 & -1.435659 & 0.1530 \\
D(CBBL) & -0.019869 & 0.009967 & -1.993582 & 0.0478 \\
C & 22.81297 & 4.568668 & 4.993352 & 0.0000 \\
\hline
\end{tabular}

$\mathrm{FDI}$, foreign direct investment; CBBL, cross border bank lending; COINTEQ01, error correction term.

TABLE 6: Panel Granger causality test results.

\begin{tabular}{lccc}
\hline Null hypothesis & $W$-statistics & $\boldsymbol{Z}$ bar-statistics & Probability \\
\hline $\begin{array}{l}\text { REM 'does not homogeneously } \\
\text { cause' Gini }\end{array}$ & 5.49031 & 1.78553 & 0.0742 \\
$\begin{array}{l}\text { GINI 'does not homogeneously } \\
\text { cause' REM }\end{array}$ & 5.97113 & 2.20870 & 0.0272 \\
$\begin{array}{l}\text { FDI 'does not homogeneously } \\
\text { cause' Gini }\end{array}$ & 5.92606 & 2.16903 & 0.0301 \\
$\begin{array}{l}\text { GINI 'does not homogeneously } \\
\text { cause' FDI }\end{array}$ & 4.02658 & 0.49729 & 0.6190 \\
$\begin{array}{l}\text { ODA 'does not homogeneously } \\
\text { cause' Gini }\end{array}$ & 3.25294 & -0.18359 & 0.8543 \\
$\begin{array}{l}\text { GINI 'does not homogeneously } \\
\text { cause' ODA }\end{array}$ & 7.02902 & 3.13976 & 0.0017 \\
$\begin{array}{l}\text { CBL 'does not homogeneously } \\
\text { cause' Gini }\end{array}$ & 2.74521 & -0.63045 & 0.0284 \\
$\begin{array}{l}\text { GINI 'does not homogeneously } \\
\text { cause' CBL }\end{array}$ & 1.38898 & -1.82407 & 0.0681 \\
\hline
\end{tabular}

REM, remittances; GINI, income inequality; FDI, foreign direct investment; ODA, foreign aid; $\mathrm{CBL}$, cross border bank lending.

\& Hsu 2012). This study found that the increasing effect of FDI on income inequality, in the long run, is strongly affected by poor economic development of the SADC region. Table 6 further indicates a unidirectional causation from FDI to income inequality. Foreign aid yielded insignificant results both in the long and short run. The weak link between foreign aid and income inequality has been documented in literature (Saidon et al. 2013). In Table 6, there is a unidirectional causality between foreign aid and income inequality.

Although cross border bank lending yielded strong effects on income inequality, results are contradicting in the long run and short run. In the short run, it can reduce income inequality, but opposite effects are found in the long run. It has been instituted that cross border bank lending can reduce income inequality in developed countries, which might be the reason for the increasing effect in the SADC as these are less developed countries (Focarelli \& Pozzolo 2001). Furthermore, the less developed SADC region is characterised by high levels of inequality as illustrated in the income distributed analysis of Milanovic (1999). The causality results impose that there is a bidirectional causality between this lending and income inequality (see Table 6).

The effects of external financial flows on income inequality can significantly converge to equilibrium at a speed of $46 \%$ 


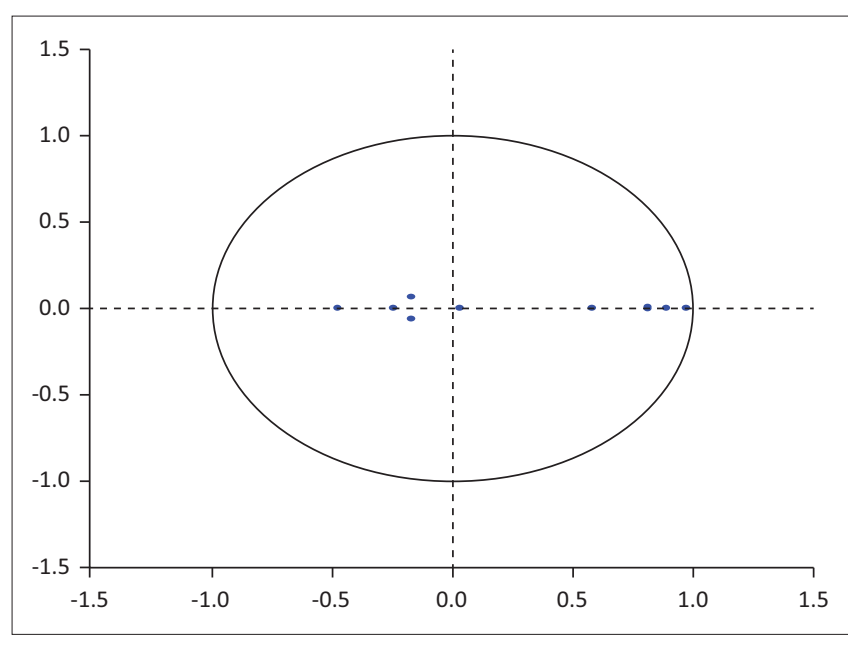

FIGURE 2: Stability test results: Inverse roots of autoregressive characteristic polynomial.

as illustrated by the error correction term in Table 5 . The series is further tested for stability and results are reported in Figure 2. The figure indicates that all the dots are inside the circle, and therefore the model is stable.

\section{Conclusion and recommendations}

The study examined the effects of external financial flows on income inequality in the SADC region for the period 1994 to 2018. For this study, external financial flows were measured by remittances, FDI, foreign aid and cross border lending, and income inequality was measured by Gini coefficient. The panel ARDL and panel causality techniques were used to examine long- and short-run coefficients and the causality relationship, respectively.

Panel cointegration techniques of Kao, Pedroni and Fisher yielded a long-run relationship in the series. The panel ARDL results yielded that in the long run, remittances can strongly reduce income inequality, and FDI and cross border bank lending have an increasing effect and foreign aid can weakly reduce inequality. In the short run, FDI and cross border bank lending can strongly explain income inequality, though negative remittances and foreign aid are insignificantly explaining income inequality. Furthermore, the evidence from panel causality confirms the bidirectional causality amongst remittances, cross border bank lending and income inequality, and unidirectional causality in other set of variables.

The article concludes that external financial flows can play a vital role in reducing persistent income inequality in the SADC region. However, the advantages and benefits of the financial flows are not automatic; sound policies and good implementation are vital to realise equal distributed of income, especially in the SADC countries. It is recommended that the SADC governments need to formulate policies on remittances, as they have positive returns on human capital, strengthen foreign aid institutions and create conducive environment to attract FDI.

\section{Acknowledgements Competing interests}

The authors have declared that no competing interests exist.

\section{Authors' contributions}

T.E.L. and T.N. contributed equally to this work.

\section{Ethical considerations}

This article followed all ethical standards for research without direct contact with human or animal subjects.

\section{Funding information}

This research received no specific grant from any funding agency in the public, commercial or not-for-profit sectors.

\section{Data availability}

The authors confirm that the data supporting the findings of this study are available within the article.

\section{Disclaimer}

The views and opinions expressed in this article are those of the authors and do not necessarily reflect the official policy or position of any affiliated agency of the authors.

\section{References}

Adams, R., Lopez-Feldman, A., Mora, J., Taylor, J.E., DeWind, J. \& Holdaway, J., 2008, 'Remittances, inequality, and poverty: Evidence from rural Mexico', in Migration and development within and across borders: Research and policy perspectives on internal and international migration, pp. 101-130, prepared for presentation at the American Agricultural Economics Association Annual Meeting, Providence, RI, the American Agriculy 24-27, 2005.
July

Adams, S. \& Klobodu, E.K.M., 2017, 'Capital flows and the distributed of income in sub-Saharan Africa', Economic Analysis and Policy 55(C), 169-178. https://doi. org/10.1016/j.eap.2017.05.006

Adger, W.N., 1999, 'Exploring income inequality in rural, coastal Viet Nam', The Journa of Development Studies 35(5), 96-119. https://doi.org/10.1080/00220 389908422593

Ali, S. \& Ahmad, N., 2013, 'A time series analysis of foreign aid and income inequality in Pakistan', Global Journal of Management and Business Research 13(5), 11-20.

Ang, J.B., 2010, 'Finance and inequality: The case of India', Southern Economic Journal 76(3), 738-761. https://doi.org/10.4284/sej.2010.76.3.738

Anyanwu, J.C., 2011, 'International remittances and income inequality in Africa', Review of Economic and Business Studies 4(1), 117-148.

Bang, J.T., Mitra, A. \& Wunnava, P.V., 2016, 'Do remittances improve income inequality? An instrumental variable quantile analysis of the Kenyan case', Economic Modelling 58(C), 394-402. https://doi.org/10.1016/j.econmod. 2016.04.004

Bansal, D., 2004, 'Foreign direct investment and performance requirements: New evidence from selected countries', Finance India 18(2), 998.

Barham, B. \& Boucher, S., 1998, 'Migration, remittances, and inequality: Estimating the net effects of migration on income distributed', Journal of Development Economics 55(2), 307-331. https://doi.org/10.1016/S0304-3878(98)90038-4

Beer, L., 2015, 'Income inequality and transitional corporate penetration', Journal of World-System Research 8(1), 1-25. https://doi.org/10.5195/jwsr.1999.144

Bhandari, B., 2007, 'Effect of inward foreign direct investment on income inequality in transition countries', Journal of Economic Integration 22(4), 888-928. https://doi. org/10.11130/jei.2007.22.4.888

Bjørnskov, C., 2010, 'Do elites benefit from democracy and foreign aid in developing countries?', Journal of Development Economics 92(2), 115-124. https://doi. org/10.1016/j.jdeveco.2009.03.001 
Breitung, J. \& Pesaran, M.H., 2008, 'Unit roots and cointegration in panels', in L. Matyas \& P. Sevestre (eds.), The econometrics of panel data, pp. 279-322, Springer, Berlin, Heidelberg.

Bremus, F. \& Fratzscher, M., 2015, 'Drivers of structural change in cross-border banking since the global financial crisis', Journal of International Money and Finance 52(C), 32-59. https://doi.org/10.1016/j.jimonfin.2014.11.012

Choi, C., 2006, 'Does foreign direct investment affect domestic income inequality?', Applied Economics Letters 13(12), 811-814. https://doi. org/10.1080/13504850500400637

Chong, A., Gradstein, M. \& Calderon, C., 2009, 'Can foreign aid reduce income inequality and poverty?', Public Choice 140(1-2), 59-84. https://doi.org/10.1007/ s11127-009-9412-4

Claessens, S. \& Perotti, E., 2005, The links between finance and inequality: Channels and evidence, background paper for the 2005, World Development Report, World Bank, University of Amsterdam, Amsterdam.

Deardorff, A.V. \& Stern, R.M. (eds.), 1994, Analytical and negotiating issues in the global trading system, University of Michigan Press, Ann Arbor, MI.

Easterly, W., 2008, Reinventing foreign aid (1), The MIT Press, Cambridge, MA.

Focarelli, D. \& Pozzolo, A.F., 2001, 'The patterns of cross-border bank mergers and shareholdings in OECD countries', Journal of Banking \& Finance 25(12), 2305-2337. https://doi.org/10.1016/S0378-4266(01)00192-3

Herzer, D., Hühne, P. \& Nunnenkamp, P., 2014, 'FDI and income inequality-Evidence from Latin American Economies', Review of Development Economics 18(4), 778-793. https://doi.org/10.1111/rode.12118

Herzer, D. \& Nunnenkamp, P., 2012, 'The effect of foreign aid on income inequality: Evidence from panel cointegration', Structural Change and Economic Dynamics 23(3), 245-255. https://doi.org/10.1016/j.strueco.2012.04.002

Heshmati, A., 2003, 'The relationship between income inequality and globalization', Citeseer 25, 20.

Jalil, A. \& Feridun, M., 2011, 'Long-run relationship between income inequality and financial development in China', Journal of the Asia Pacific Economy 16(2) 202-214. https://doi.org/10.1080/13547860.2011.564745

Jaumotte, F., Lall, S. \& Papageorgiou, C., 2013, 'Rising income inequality: Technology, or trade and financial globalization?', IMF Economic Review 61(2), 271-309. https://doi.org/10.1057/imfer.2013.7

Jensen, N.M. \& Rosas, G., 2007, 'Foreign direct investment and income inequality in Mexico, 1990-2000', International Organization 61(3), 467-487. https://doi. org/10.1017/S0020818307070178

Jones, R.C., 1998, 'Remittances and inequality: A question of migration stage and geographic scale', Economic Geography 74(1), 8-25. https://doi.org/ $10.2307 / 144341$

Koechlin, V. \& Leon, G., 2007, 'International remittances and income inequality: An empirical investigation', Journal of Economic Policy Reform 10(2), 123-141. https://doi.org/10.1080/17487870701346514
Lin, S.C., Kim, D.H. \& Wu, Y.C., 2013, 'Foreign direct investment and income inequality: Human capital matters', Journal of Regional Science 53(5), 874-896. https://doi. org/10.1111/jors.12077

Linardi, S. \& Rudra, N., 2016, Globalization and redistribution towards the poor in developing countries: Experiment in India, Working Paper, University of Pittsburgh, Pittsburgh, PA.

Marjit, S., Beladi, H. \& Chakrabarti, A., 2004, 'Trade and wage inequality in developing countries', Economic Inquiry 42(2), 295-303. https://doi.org/10.1093/ei/cbh061

Milanovic, B., 1987, 'Remittances and income distributed', Journal of Economic Studies 14(5), 24-37. https://doi.org/10.1108/eb002657

Milanovic, B., 1999, 'Explaining the increase in inequality during transition', Economics of Transition 7(2), 299-341. https://doi.org/10.1111/1468-0351.00016

Ncanywa, T. \& Mabusela, K., 2019, 'Can financial development influence economic growth: The sub-Saharan analysis?', Journal of Economic and Financial Sciences 12(1), 1-13. https://doi.org/10.4102/jef.v12i1.194

Ostry, M.J.D., Berg, M.A. \& Tsangarides, M.C.G., 2014, Redistribution, inequality, and growth, International Monetary Fund, Washington, DC.

Pesaran, M.H., Shin, Y. \& Smith, R.P., 1999, 'Pooled mean group estimation of dynamic heterogeneous panels', Journal of the American Statistical Association 94(446), 621-634. https://doi.org/10.1080/01621459.1999.10474156

Ranciere, R., Throckmorton, M.N.A., Kumhof, M.M., Lebarz, M.C. \& Richter, M.A.W., 2012, Income inequality and current account imbalances (No. 12-18), International Monetary Fund, Washington, DC

Saidon, R., Yusop, Z., Ismail, N.W. \& Hoo, L.S., 2013, 'Sectoral foreign aid and income inequality', International Journal of Economics and Finance 5(9), 117-122. https:// doi.org/10.5539/ijef.v5n9p117

Shafiullah, M., 2011, 'Foreign aid and its impact on income inequality', International Review of Business Research Papers 7(2), 91-105.

Stolper, W.F. \& Samuelson, P.A., 1941, 'Protection and real wages', The Review of Economic Studies 9(1), 58-73. https://doi.org/10.2307/2967638

Sylwester, K., 2005, 'Foreign direct investment, growth and income inequality in less developed countries', International Review of Applied Economics 19(3), 289-300. https://doi.org/10.1080/02692170500119748

Taylor, J.E., 1992, 'Remittances and inequality reconsidered: Direct, indirect, and intertemporal effects', Journal of Policy Modelling 14(2), 187-208. https://doi. org/10.1016/0161-8938(92)90008-Z

Te Velde, D.W., 2003, Foreign direct investment and income inequality in Latin America: Experiences and policy implications (No. 04/03), Research Institute Socio-Economics (IISEC), Bolivian Catholic University, La Paz.

World Bank, 2020, World Bank open data, viewed 15 February 2020, from https:// data.worldbank.org/.

Wu, J.Y. \& Hsu, C.C., 2012, 'Foreign direct investment and income inequality: Does the relationship vary with absorptive capacity?', Economic Modelling 29(6), 2183-2189. https://doi.org/10.1016/j.econmod.2012.06.013 